\title{
The Cinematic Society and the Reflexive Interview
}

\author{
Norman K. Denzin
}

Published online: 14 June 2012

(C) Springer Science+Business Media, LLC 2012

Think of how much we learn about contemporary life by way of interviews. Larry King introduces us to presidents and power brokers. Barbara Walters plumbs the emotional depths of stars and celebrities. Oprah ... and Geraldo invite the ordinary, tortured and bizarre to 'spill their guts to millions of home viewers (Holstein and Gubrium, 1995, p. 1).

We inhabit a second-hand world, one already mediated by cinema, television and the other apparatuses of the postmodern society. In this world, culture is driven less and less by the technological innovation of the written word, and increasingly by the interactive conventions of dramaturgy, performance and the media. We have no direct access to this world, we only experience and study its representations. A reflexive sociology studies society as a dramaturgical production. The reflexive interview is a central component of this interpretive project. ${ }^{1}$

In this article I examine the nexus of the cinematic and the interview society. I show how the postmodern has have become an interview society, how our very subjectivity "comes to us in the form of stories elicited through interviewing" (Holstein and Gubrium 2000, p. 129; Atkinson and Silverman 1997). The interview, whether conducted by social researchers, mass media reporters, television journalists, therapists, or counselors, is now an ubiquitous method of self construction (Holstein and Gubrium 2000, p. 129).

I will discuss the concept of the active, dialogical interview, anchoring this complex formation in the postmodern, cinematic society (Holstein and Gubrium 1995, 1997; Jackson 1998; Denzin 1995a, b; 1997; Scheurich 1995). The

\footnotetext{
${ }^{1}$ See Denzin $(1991,2000 ; 2003)$ for earlier versions of this essay.

N. K. Denzin $(\triangle)$

College of Media, University of Illinois,

228 Gregory Hall 810 South Wright Street,

Urbana, IL 61801, USA

e-mail: n-denzin@illinois.edu
}

reflexive interview is simultaneously a site for conversation, a discursive method, and a communicative format that produces knowledge about the self and its place in the cinematic society; that society which knows itself through the reflective gaze of the cinematic apparatus. A cinematic sociology requires a concept of the reflexive interview.

A single two-sided question organizes my argument, namely: "How does the postmodern, cinematic world mediate the ways in which we represent ourselves to ourselves?" and "What is the place of the interview-interviewer relationship in this production process?" My argument unfolds thusly. I begin by outlining the central features of the postmodern, cinematic, interview society. I then show how the interview, and the interviewer, as a voyeur, are basic features of this society. I thicken this argument by demonstrating how popular media representations shape and define situated cultural identities. I show how these representations become anchor points for the postmodern self; that is they occupy a central place in the background of our cultural consciousness. They mediate structures of meaning in the cinematic-interview society. A circular model of interpretation is thus created. Interviews, interviewers and story-tellers are defined in terms of these dominant cultural images and understandings. Thus does the cinematic society structure the interview society, and vice verse. I conclude with a series of epistemological observations on the significance of the relation between the cinematic society and the reflexive interview (see also Mishler 1986; Heyl 2000; Burawoy 1998; Bourdieu 1996).

\section{The Postmodern, Cinematic Society}

Members of the postmodern society know themselves through the reflected images and narratives of cinema and television. On this Altheide (1995, p. 59) observes, "culture 
is not only mediated through mass media ... culture in both form and content is constituted and embodied by the mass media." The postmodern landscape is distinguished, as Gottschalk (2000) argues by "its constant saturation by multiple electronic screens which simulate emotions, interactions, events, desires ... From TV screens to computer terminals, from surveillance cameras to cell phones, we increasingly experience everyday life, reality ... via technologies of spectacle, simulation and "telepresence"" (p. 23).

Consider the following exchange between ESPN sports journalist Sal Palatonio and Kurt Warner, quarterback of the St. Louis Rams, the Most Valuable Player of the 2000 Superbowl.

Sal: "There's a minute and $54 \mathrm{~s}$ left in the game. The Titans have just tied the score. Now look let me show you your 73-yard winning pass to Isaac Bruce. Kurt, what were you thinking when Isaac caught that pass?" Kurt: (Looks up at replay): "We'd called the same play earlier and Isaac was open. So we thought it would work. It was a go route. We thought we could get a big one right off the bat. I just thought it was meant to be, it was meant to work."

Sal: "This has been a terrific year for you. Five years ago you

were sacking groceries in the IGA. Two years ago you were playing arena football in Cedar Rapids, Iowa. This is better than a Hollywood script. Tell me how you feel about what has happened to you this year?" Kurt: "I don't think of it as a Hollywood story. It's my life. I take it one day at a time.

Sal: "It has not been easy, has it?'

Kurt: "I was getting to the point of thinking how much longer am I going to have before people say he is too old to give him an opportunity. It has been tough for us until this last year. Even when I was playing arena football we did all right, but a lot of tough decisions .... When I first started dating my wife, she was on food stamps, and I was in between jobs. That is why I ended up stocking shelves; I had to do something at nights so I could work out and keep my chances in football. A lot of things like that have helped keep things in perspective, even though we are not making a million dollars, we are very fortunate to be where we are at, in this position, and don't look beyond that, don't take anything for granted."

Sal: Thanks Kurt. Is there anything else you want to say?" Kurt: "I'm truly blessed. If I can he a source of hope to anybody, I'm happy to be a part of it. The good lord has blessed me. I am on a mission. He has called me to do this. I can only share my testimony with others.
Thank you Jesus" (ESPN Sports Center, 31 January

2000; also Vecesy 2000).

Kurt's self-narrative is grafted into the replay of the winning touchdown pass. Indeed this Superbowl victory symbolizes the larger-than-life-triumph that Warner has experienced over the course of the last five years. Sal elicits this self-story by asking Warner how he feels about his award-winning year, comparing it to a Hollywood script. Kurt complies by giving him a socially acceptable answer; indeed Palatonio's questions establish the right for Warner to give this extended account of his life and what it means (see also Holstein and Gubrium 2000, p. 129). The viewer vicariously shares in this experience. ${ }^{2}$

The ingredients of the postmodern self are modeled in the media. The postmodern self has become a sign of itself, a double dramaturgical reflection anchored in media representations on one side, and everyday life on the other. These cultural identities are filtered through the personal troubles and the emotional experiences from the individual's interactions with everyday life. These existential troubles connect back to the dominant cultural themes of the postmodern era. The electronic media and the new information technologies turn everyday life into a theatrical spectacle where the dramas that surround the decisive performances of existential crises are enacted. This creates a new existential "videocy", a language of crisis coded in electronic, media terms.

The media structure these crises and their meanings. A 38-year-old male alcoholic is standing outside the door to where A. A. meetings are held. He asks:

"How do I get into one of those A. A. meetings? What do I say? I seen them in the movies. That Michael Keaton in Clean and Sober. He went to one of them. He just stood up and said he was an alcoholic. Do I have to do that? I ain't even sure I am one, but I drank a fifth of Black Jack last night and I started up agin this mornin'. I'm scared" (Denzin 1995b, p. 260)

This is a postmodern story waiting to be heard, already partially told through the figure of Michael Keaton, himself a actor, playing a fictional character (Daryl), who went to a fictional A. A. meeting in a Hollywood film. Texts within texts, movies, everyday life, a man down and out on his luck, A.A., a door into a building where meetings are held, anxiety, fear. The everyday existential world connects to the cinematic apparatus, and our drunk on the street hopes to

\footnotetext{
${ }^{2}$ The underlying logic of the sports interview is mocked in the following dialogue in Ron Shelton's 1988 film Bull Durham. Kevin Costner, who plays an aging pitcher, "Crash Davis", says to his protégé played by Tim Robbins, "Now you are going to the Big Show. You have to learn how to talk to interviewers. When they ask you how it feels to be pitching in Yankee Stadium, you say, 'I just thank the good Lord for all his gifts. I owe it all to him. I just take it one game, one pitch at a time."”
} 
begin a story that will have a happy ending, like Michael Keatons.

\section{The Birth of Cinematic Surveillance}

In the space of thirty years (1900-1930) cinema became an integral part of American society. Going to the movies became a weekly pastime for millions of Americans. Motion pictures became a national institution. Hollywood stars became personal idols, fan clubs were formed and a movie theater with its marquee was a permanent part of virtually every American community.

The cinematic, surveillance society soon became a disciplinary structure filled with subjects (voyeurs) who obsessively looked and gazed at one another, as they became, at the same time, obsessive listeners, eaves-droppers, persons whose voices and telephone lines could be tapped, voices that could be dubbed, new versions of the spoken and seen self. A new social type, was created; the voyeur, or Peeping Tom, who would, in various guises (ethnographer, social scientist, detective, psychoanalyst, crime reporter, investigative journalist, innocent-by-stander, sexual pervert), elevate the concepts of looking and listening to new levels.

With the advent of color and sound in the mid-1920s, there was a drive toward cinematic realism. This impulse to create a level of realism that mapped everyday life, complimented the rise of naturalistic realism in the American novel and the emergence of hardnosed journalistic reporting by the major American newspapers, radio (and later TV) stations (Denzin 1997, p. 21-22). During the same time period an ethnographic, psychoanalytic, and life history approach was taking hold in the social sciences, and society-at-large. Like journalists, sociologists, market and survey researchers were learning how to use the interview to gather and report on the facts of social life (Fontana and Frey 1994, p. 362; 2000; Denzin 1997, p. 129).

Robert E. Park, a founder of the Chicago School of ethnographic research (Vidich and Lyman 1994, pp. 32-33) clarifies this relationship between journalism, social science and the use of the interview:

After leaving college, I got a job as a reporter .... I wrote about all sorts of things .... My interest in the newspaper had grown out of the discovery that a reporter who had the facts was a more effective reformer than an editorial writer .... According to my earliest conception of a sociologist he was to be a kind of super-reporter .... He was to report a little more accurately, and in a little more detail (Park 1950, pp. v, vii-ix).

And so although sociologists and journalists both used interviews, the duties and practices of the two occupational groups were separated. Organizing surveillance in their distinct ways.

\section{The Interview Society}

The interview society emerges historically as a consequence, in part, of the central place that newspapers, cinema (and television) came (and continue) to occupy in daily life. The media, human service personnel, market researchers and social scientists "increasingly get their information via interviews' (Holstein and Gubrium (1995, p. 1). The interview society has turned the confessional mode of discourse into a public form of entertainment (Atkinson and Silverman 1997, pp. 309-315; Holstein and Gubrium 2000, p.129). The world of private troubles, the site of the authentic, or real self, has become a public commodity.

\section{The Interview Goes to Hollywood}

It remained for Hollywood to authorized the interview as a primary method of gathering information about social issues, selves, and the meanings of personal experience. Soon Hollywood was telling stories about newspaper reporters (The Front Page, 1931), detectives and private eyes (Maltese Falcon, 1931, 1941), psychoanalysts and psychiatrists (Spellbound, 1945), spies and secret agents (Saboteur, 1942), market researchers (Desk Set, 1957), (Sex and the Single Girl, 1964), and more recently offering spoofs about sociologists (The Milagro Beanfield War, 1988), and anthropologists (Krippendorf's Tribe, 1998).

Each of these film genres glamorized the interview as a form of interaction, and as a strategy and technique for getting persons to talk about themselves and others (see Holstein and Gubrium 1995, p. 3). Journalists, detectives, and social scientists were presented as experts in the use of this conversational form. It was expected that they would use this form when interacting with members of society. Furthermore, it was expected that persons, if properly asked, would reveal their inner selves to such experts.

And thus the key assumptions of the interview society were soon secured. The media and Hollywood cinema helped solidify the following cluster of beliefs: only skilled interviewers and therapists (and sometimes the person) have access to the deep, authentic self of the person; sociologists, journalists, and psychoanalysts know how to ask questions which will produce disclosures, often discrediting, about the hidden self; members of the interview society have certain experiences that are more authentic then others, and these experiences are keys to the hidden self. (These are the experiences that have left leave deep marks and scars on the person.) Adept interviewers can uncover these 
experiences and their meanings to the person. Nonetheless, persons also have access to their own experiences; this increases the value of first-person narratives which are the site of personal meaning.

When probing for the inner self, or when seeking information from the person, interviewers are expected to use some method to record what is said in the interview. In the film True Crime (1999) Clint Eastwood plays Steve Everett, a burnt-out, alcoholic reporter who becomes convinced that Luther Beachum, a black man due to die within twenty-four hours in San Quentin is innocent. Eastwood tracks down Mr. Porterhouse, the man whose testimony led to Luther's conviction. Everett and Porterhouse meet in a café and the following exchange unfolds.

Everett: "Let me get this straight, you didn't really see the murder?

Porterhouse: "I never said I did."

Everett: "What did you see?"

Porterhouse: "I can't tell you how many times I've been over this. I went into Pokeums to use the phone. My car had overheated. Beachum jumped up from behind the counter. He was covered with blood and had a gun in his hand. He was bending over, stealing her necklace. He got one good look at me and then he ran out the store My concern was for the girl. So I immediately dialed 911. I figured why should I run after a killer, when the police should do their job."

Everett: "And they sure did it, didn't they."

Porterhouse: "Aren't you gonna take some notes, or somethin'?

Or use a tape recorder? Usually when I'm talkin' to a reporter they wanta keep some sort of record of what I've been sayin'

Everett: "I have a photographic memory (points to head). I have a note book right here" (which he pulls out of his jacket pocket, holding a pen in his hand).

Eastwood refuses to write anything in his note book, and Porterhouse challenges him, "I did some checking on you. You're the guy who lead the crusade to get the rapist released. That lying what' his name? Had all your facts straight on that one too, didn't you."

Everett next interviews Frank in his prison cell. Frank's wife is with him. (The reporter assigned to the case was killed in an auto accident.)

Luther: "I guess you wanta hear how it feels to be in here."

Everett: "Yeah, it's a human interest piece."

Luther: "I feel isolated. I feel fear, pain, fear of prison, fear of being separated from my loved ones. All those fears rolled up into one."

Everett: Takes notebook out of pocket.
Luther: "I want to tell everyone that I believe in Jesus Christ, our Lord and Savior"

Everett: Scribbles on page of notebook: BLV, JC.

Luther: "I came into my faith late in life. Did a lot of bad things... I believe that the crooked road remains straight, that' what the bible says."

Everett: Scribbles on page of notebook: LORD, SAV, CARO, STRAIT.

Luther: "Is there anymore that you want?"

Everett: "You don't know me. I'm just a guy out there with a screw loose. Frankly I don't give a rat's ass about Jesus Christ. I don't even care what' right or wrong. But my nose tells me something stinks, and I gotta have my faith in it, just like you have your faith in Jesus... I know there' truth out there somewhere... I believe you.

Wife: "Where were you?"

Everett: "It wasn't my story."

Luther clearly expected Everett to ask him how he felt about being on death row. Frank expected to tell a reporter a deeply personal story about what this experience means to his inner, authentic self. Indeed Everett's presence in the prison elicits such a story from Frank. Paraphrasing Holstein and Gubrium (2000, p. 129), the prison interview with a journalist is now a natural part of the death row identity landscape. But Everett, through his note taking, mocks this assumption. He has no desire to record the inner meaning of this experience for Frank. This is unlike Sal Palitino (above), who sought and got from Kurt Warner, a selfvalidating, self-congratulatory story about hard work and success in American life.

\section{The Interview Machine as an Epistemological Apparatus}

The interview society uses the machinery of the interview to methodically produce situated versions of the self. This machinery works in a systematic and orderly fashion. It structures the talk that occurs in the interview situation. There is an orderly mechanism "for designating who will speak next" (Holstein and Gubrium 2000, p. 125). Using the question-answer format, this mechanism regulates the flow of conversation. Talk occurs in question-answer pairs, for the asking of a question requires an answer. Turn-taking structures this give-and-take. The rule of single-speakership obtains, one persons speaks at a time. Interviews, in this sense, are orderly, dramaturgical accomplishments. They draw on local understandings, and are constrained by those understandings. They are narrative productions, they have beginnings, middles, and endings. 
The methodology of asking questions is central to the operation of this machine. Different epistemologies and ideologies shape this methodological practice. Four epistemological formats can be identified; the objectively neutral format, the entertainment and investigative format, the collaborative, or active interview format, and the reflexive, dialogical interview. ${ }^{3}$

For each format, the asking of a question is an incitement to speak, an invitation to tell a story, in this sense the interview elicits narratives of the self (Holstein and Gubrium 2000, p. 129). The place of the interviewer in this process varies dramatically. In the objectively neutral format, the interviewer, using structured, or semi-structured interview schedules, attempts to gather information, without influencing the story that is being told. Holstein and Gubrium (2000) correctly observe that the demands of ongoing interaction make the "'ideal' interview a practical impossibility, because the interview itself always remains accountable to the normative expectancies of competent conversation as well as to the demand for a good story to satisfy the needs of the researcher" (p. 131).

In the entertainment format, the interviewer often acts as a partisan, seeking to elicit a story that will sell as an entertainment commodity, or be marketed as a new piece of information about a story that is in the process of being told. In the entertainment-investigative format, the interviewer asks leading, aggressive questions, as well as friendly questions, questions that allow the subject to embellish on a previous story, or to give more detail on the meanings of an important experience.

Palatonio's interview with Warner (above) employs the entertainment format. This is a friendly interview, that shows both Warner and Palatonio in a good light. Steve Everett's interview in True Crime with Mr. Porterhouse deploys the investigative version of this format. Everett is aggressive, and hostile. He seeks to discredit Porterhouse as a witness.

In the collaborative-active format, interviewer and respondent tell a story together (see Holstein and Gubrium 1995, pp. 76-77). In this format a conversation occurs. Indeed the identities of interviewer and respondent will disappear. Each person becomes a storyteller, or they collaborate in telling a conjoint story. This is what occurs in the ESPN interview, together Sal and Kurt tell a story about the meaning of this victory for Kurt's life.

With the reflexive, interview format, two speakers enter into a dialogical relationship with one another. In this relationship, a tiny drama is played out. Each person becomes a party to the utterances of the other. Together, the two

\footnotetext{
${ }^{3}$ These interview formats blur with the three types of relationships Mishler (1986) identifies between interviewers and interviewees: informants and reporters, collaborators, and advocates.
}

speakers create a small dialogical world of unique meaning and experience. In this interaction each speaker struggles to understand the thought of the other, reading and paying attention to such matters as intonation, facial gestures, word selection and so on (see Bakhtin 1986, pp. 92-93).

Consider the following exchange taken from Wayne Wang's 1981 Chan is Missing. Set in contemporary San Francisco, the film mocks popular culture, representations of stereotypical Asian-American identities. It also mocks social science and those scholars who point to language is a answer to cultural differences. The following Lily Tomlinlike monologue is central to this position. In the speaker's monologue racial and ethnic identities are constructed. This construction is directly connected to the use of the objective interview format. The speaker is a female Asian-American attorney. She is attempting to find $\mathrm{Mr}$. Chan, who had an automobile accident, just days before he disappeared. She is speaking to Jo, a middle-aged Chinese American cabdriver, and his young "Americanized" nephew Steve. They are at Chester's Cafe. The young attorney is dressed in a black masculine-style suit, with a white shirt and dark tie.

You see I'm doing a paper on the legal implications of cross-cultural misunderstandings. (nods head). Mr. Chan's case is a perfect example of what I want to expose. The policeman and Mr. Chan have completely different culturally related assumptions about what kind of communication about communication (shot of Steve, then Jo) each one was using. The policeman, in an English speaking mode, asks a direct factual question"did you stop at the stop sign?" He expected a "yes or a no" answer. Mr. Chan, however, rather than giving him a yes or a no answer began to go into his past driving record-how good it was, the number of years he had been in the United States, all the people that he knewtrying to relate different events, objects or situations to what was happening then to the action at hand. Now this is very typical ... The Chinese try to relate points, events or objects that they feel are pertinent to the situation, which may not to anyone else seem directly relevant at the time ... This policeman became rather impatient, restated the question, "Did you or did you not stop at the stop sign? in a rather hostile tone, which in turn flustered Mr. Chan, which caused him to hesitate answering the question, which further enraged the policeman, so that he asked the question again, "You didn't stop at the stop sign, did you?" in a negative tone, to which Mr. Chan automatically answered "No." Now to any native speaker of English "No" would mean "No I didn't stop at the stop sign. “ However to Mr. Chan "No I didn't stop at the stop sign" was not "No I didn't stop at the stop sign (Jo shakes head, looks away). It was No, I didn't not stop at 
the stop sign." In other words "Yes I did stop at the stop sign." Do you see what I'm saying? (camera pans room)

Jo (voice-over) "Chan Hung wouldn't run away because of the car accident. I'm feeling something might have happened to him" (see Denzin 1995a, p. 105).

Here our speaker, the young attorney, attempts to dialogically enter into and interpret the meanings that were circulating in Mr. Chan's interview with the policeman. In so doing she criticizes the concept of cross-cultural communication, showing through her conversation that meanings are always dialogic and contextual.

This text from Wang's film is an example of how the reflexive, dialogic interviewer deconstructs the uses and abuses of the interview; uses that are associated with the objectively neutral, entertainment and investigative formats. Wang's text suggests that interpretations based on the surface meanings of an utterance sequence are likely to be superficial. To paraphrase Dillard (1982), serious students of society take pains to distinguish their work from such interpretive practices (1982, p. 46).

At another level reflexively oriented scholars, such as Bakhtin, contend that there is no essential self or private, or real self behind the public self. They argue that there are only different selves, different performances, different ways of being a gendered person in a social situation. These performances are based on different interpretive practices. These practices give the self and the person a sense of grounding, or narrative coherence (Gubrium and Holstein 1998, p. 165). There is no inner, or deep self that is accessed by the interview or narrative method. There are only different interpretive (and performative) versions of who the person is.

Steve Everett embodies one version of the reflexive interviewer. He has no interest in the inner self of the person he is interviewing, no interest in right or wrong.. He only seeks the truth, the truth that says an injustice may have been done. Wang's Asian-American attorney is another version of this interviewer, she understands that the self is a verbal and narrative construction.

\section{The Interview and the Dramaturgical Society}

The text from the Kurt Warner interview suggests that the metaphor of the dramaturgical society (Lyman 1990, p. 221), or "life as Theater" (Brissett and Edgley 1990, p. 2; Goffman 1959, pp. 254-55) is no longer a metaphor. It has become interactional reality. Life and art have became mirror images of one another. Reality, as it is visually experienced, is a staged, social production.

Raban (1981) provides an example of how life and television coincide. In a TV ad "beamed by the local station in Decorah, an Iowa farmer spoke stiffly to the camera in testimony to the bags of fertilizer that were heaped in front of him" (p. 123). Here the personal testimony of the farmer, a hands-on expert, authorizes the authenticity and value of the product. This message is carried live, staged in the frame of the TV commercial, a real farmer says this product works. The farmer's awkwardness comes, perhaps, from the fact that he must look at himself doing this endorsement, knowing that if he sees himself looking this way, others will as well.

The reflected, everyday self and its gendered presentations are attached to the cinematic/televisual self. Blumer provides an example. An interview respondent connects her gendered self to the Hollywood screen:

Female, 19, white, college freshman. -When I discovered

I should have this coquettish and coy look which all girls may have, I tried to do it in my room. And surprises! I could imitate Pola Negri's cool or fierce look. Vilma Banky's sweet and coquettish attitude. I learned the very way of taking my gentlemen friends to and from the door with that wistful smile, until it has become a part of me (Blumer 1933, p. 34).

Real, everyday experiences are judged against their staged, cinematic, video-counterpart. The fans of Hollywood stars dress like the stars, make love like the stars, and dream the dreams of the stars. Blumer provides an example.

Female, 24, white, college senior.--During my highschoolperiod I particularly liked pictures in which the setting was a millionaire's estate or some such elaborate place. After seeing a picture of this type, I would imagine myself living such a life of ease as the society girl I had seen. My day-dreams would be concerned with lavish wardrobes, beautiful homes, servants, imported automobiles, yachts, and countless suitors" (Blumer 1933, p. 64).

With this dramaturgical turn, the technology of the media "disengages subjects from their own expressions ... Individuals become observers of their own acts ... Actions come to be negotiated in terms of a media aesthetic, both actor and spectator live a reality arbitrated by the assumptions of media technicians" (Eason 1986, p. 60). Altheide and Snow (1991) provide an example from the Richard Nixon Presidency. In a December 1, 1969 memo to H. R. Haldeman, Nixon wrote:

"We need a part-or full-time TV man on our staff for the purpose of seeing that my TV appearances are handled on a professional basis. When I think of the millions of dollars that go into one lousy 30 -second television spot advertising deodorant, it seems to me 
unbelievable that we don't do a better job of seeing that Presidential appearances [on TV] always have the very best professional advice" (Altheide and Snow 1991, p. 105; also Oudes 1989, p. 46

And because of the same media aesthetic, Kurt Warner has learned how to talk that form of sports talk Ron Shelton mocks in Bull Durham. So too does Frank Beachum expect Steve Everett to record his moral story.

The main carriers of the popular in the postmodern society have become the very media that are defining the content, and meaning of the popular; that is popular culture is now a matter of cinema and the related media, including television, the press and popular literature. A paradox is created, for the everyday is now defined by the cinematic and the televisual. The two can no longer be separated. A press conference at the 1988 National Democratic Political Convention is reported thusly:

A dozen reporters stood outside CBS's area, and as was so often the case at the convention, one began interviewing another. A third commented wryly on the interview: "Reporter interviews reporter about press conference" (Weiss, Philip 1988, pp. 33-34; also quoted in Altheide and Snow 1991, p. 93)

Reporters reporting on reporters interviewing reporters.

\section{Studying the Interview in Cinematic Society}

The cinematic apparatuses of contemporary culture stand in a two-fold relationship to critical inquiry. First, the cultural logics of the post-video, cinematic culture define the lived experiences that a critical studies project takes as its subject matter. How these texts structure, and give meaning to the everyday must be analyzed. At the same time, critical ethnographies of the video-cinematic text must be constructed, showing how these texts map and give narrative meaning to the crucial cultural identities that circulate in the postmodern society.

Consider race, the racial self, and Hollywood cinema. Lopez reminds us that, "Hollywood does not represent ethnics and minorities; it creates them and provides an audience with an experience of them "(Lopez 1991, pp. 404-405). Consider Lopez's arguments in terms of the following scene from Spike Lee's highly controversial 1989 film Do the Right Thing. Near the film's climax, as the heat rises on the street, Lee has members of each racial group in the neighborhood hurl vicious racial slurs at one another:

Mookie (to Sal and his Italian sons-Vito and Pino): "Dago, Wop, guinea, garlic breath, pizza slingin' spaghetti bender, Vic Damone, Perry Como, Pavarotti." Pino (to Mookie and the blacks):
"Gold chain wearin' fried chicken and biscuit eatin' monkey, ape, baboon, fast runnin', high jumpin', spear chuckin', basketball dunkin' ditso spade, take you fuckin' pizza and go back to Africa."

A Puerto Rican man (to the Korean Grocer:

"Little slanty eyed, me-no speakie American, own every fruit and vegetable stand in New York, Bull Shit, Reverend Sun Young Moon, Summer 88 Olympic kick-ass boxer, sonofabitch."

White policeman:

"You goya bean eatin' 15 in the car. 30 in the apartment, pointy red shoes wearin' Puerto Ricans,

cocksuckers."

Korean grocer:

"I got good price for you, how am I doing? Chocolate, egg cream drinking, bagel lochs, Jew ass-hole."

Sweet Dick Willie (to the Korean grocer):

"Korean motherfucker ...you didn't do a goddamn thing except sit on your monkey ass here on this corner and do nothin" (see Denzin 1991, pp. 129-130).

Lee's wants his viewers to believe that his speakers are trapped within the walls and streets of a multiracial ghetto, that is the Bedford-Stuyvesant area of New York. Their voices reproduce current, (and traditional) cultural, racial and sexual stereotypes about blacks (spade, monkey), Koreans (slanty eyed), Puerto Ricans (pointy red shoes, cocksuckers), Jews (begel lochs), and Italians (Dago, wop). The effects of these "in-your face insults" are exaggerated through wide-angled, close-up shots. The speaker's face literally fills the screen as the racial slurs are heard. ${ }^{4}$

Lee's film presents itself as a realist, ethnographic text. It asks the viewer to believe that it is giving an objectively factual, authentic, and realistic account of the lived experiences of race and ethnicity. The film performs race and ethnicity (Lee's Pino talking to Mookie), and do so in ways that support the belief that objective reality has been captured. The film "realistically" reinscribes familiar (and new) cultural stereotypes, for example young gang members embodying hop hop, rap culture. Lee's text functions like a documentary film.

\section{The Cinematic Society and the Documentary Interview}

It is this documentary impulse and its reliance on the objectively neutral interview format that I now examine. I do so through an analysis of Trinh T. Minh-ha's 1989 film,

\footnotetext{
${ }^{4}$ While prejudice crosses color lines in this film, racial intolerance is connected to the psychology of the speaker (e.g. Vito). It is "rendered as the how of personal bigotry " (Guerrero 1993, p. 154, italics in original). The economic and political features of institutional racism are not taken up. That is, in Lee's film. "the why of racism is left unexplored" (Guerrero 1993, p. 154, italics in original).
} 
Surname Viet Given Name Nam. This is a film about Vietnamese women whose names change and remain constant, depending on whether or not they marry a foreigner or a Vietnamese. In this film Trinh (1992, p. 49) has Vietnamese women speak from five different subject positions representing lineage, gender and age status, leadership position, and historical period. This creates a complex picture of Vietnamese culture (1992, p. 144).

The film is multi-textual, layered with pensive images of women in various situations. Historical moments overlap with age periods (childhood, youth, adulthood, old age), ritual ceremonies (weddings, funerals, war, the market, dance), and daily household work (cooking), while interviewees talk to off-screen interviewers. There are two voiceovers in English, a third voice sings sayings, proverbs, and poetry in Vietnamese (with translations as texts on the screen). There are also interviews with Vietnamese subtitled in English, and interviews in English synchronized with the on-screen image (Trinh 1992, p. 49). The interviews are reenacted in Trinh's film by Vietnamese women, who are then interviewed at the end of the film, asked about their experiences of being performers in the film (1992, p. 146).

The film allows the practice of doing reflexive interviews to enter into the construction of the text itself, thus the true and the false, the real and the staged intermingle, indeed the early sections of the film unfold like a traditional, realist documentary film (1992, p. 145). The viewer does not know these are actresses re-enacting interviews. Nor does the viewer know that the interviews were conducted in the United States, not Vietnam. (This only becomes apparent near the end of the film.)

In using these interpretive strategies, Trinh creates the space for the critical appraisal of the politics of representation that structure the use of interviews in the documentary film. In undoing the objectively neutral interview as a method for gathering information about reality, Trinh takes up the question of truth (1992, p. 145). Whose truth is she presenting, that given in the on-screen interview situation, or that of the women-asactresses who are interviewed at the end of the film?

Trinh begins by deconstructing the classic interview-based documentary film which enters the native's world and brings news from that world to the world of the western observer. In its use of the traditional, non-dialogical interview method, documentary film, like Spike Lee's Do The Right Thing, starts with the so-called real world and the subject's place in that world. It uses an aesthetic of objectivity, and a technological apparatus which produces truthful statements (images) about the world (1991, p. 33). Trinh argues that the following elements are central to this apparatus (1991, pp. 33-36):

-• the relentless pursuit of naturalism which requires a connection between the moving image and the spoken word;
•• authenticity - the use of people who appear to be real, and locating these people in 'real' situations;

• the filmmaker interviewer is presented as an observer, not as a person who creates what is seen, heard and read; •• only events, unaffected by the recording eye, should be captured;

•• the film-interview captures objective reality;

•• truth can be dramatized;

- actual facts should be presented in a credible way, with people telling them;

•• the film-interview text must convince the spectator that they should have confidence in the truth of what they see (1991, p. 39).

These aesthetic strategies define the documentary interview style, allowing the filmmaker-as-interviewer to create a text which gives the viewer the illusion of having "unmediated access to reality" (1991, p. 40). Thus naturalized, the objective, documentary interview style has become part of the larger cinematic apparatus in American culture, including a pervasive presence in TV commercials and news (1991, p. 40).

Trinh brings a reflexive reading to these features of the documentary film, citing her own texts as examples of dialogic documentaries that are sensitive to the flow of fact and fiction, to meanings as political constructions (1991, p. 41). Such texts reflexively understand that reality is never neutral, or objective, that it is always socially constructed. Filmmaking and documentary interviewing thus become methods of 'framing' reality.

Self-reflexivity does not translate into personal style, or a preoccupation with method. It rather centers on the reflexive interval that defines representation, "the place in which the play within the textual frame is a play on this very frame, hence on the borderlines of the textual and the extra-textual" (1991, p. 48). The film becomes a site for multiple experiences.

A responsible, reflexive, dialogical interview text embodies the following characteristics (1991, p. 188):

-• it announces its own politics and evidences a political consciousness;

- it interrogates the realities it represents;

• it invokes the teller's story in the history that is told;

• it makes the audience responsible for interpretation;

-• it resists the temptation to become an object of consumption;

•• it resists all dichotomies (male/female, etc.);

- it foregrounds difference, not conflict;

-• it uses multiple voices, emphasizing language as silence, the grain of the voice, tone, inflection, pauses, silences, repetitions;

•• silence is presented as a form of resistance.

Trinh creates the space for a version of the cinematic apparatus and the interview machine that challenges 
mainstream film. She also challenges traditional ethnography and its use of objective and investigative interview formats.

Reflexive texts question the very notion of a stable, unbiased gaze. They focuse on the pensive image, on silences, on representations which "unsettle the male apparatus of the gaze" (1991, p. 115). This look makes the interviewer's gaze visible. It destabilizes any sense of verisimilitude that can be brought to this visual world. In so doing it also disrupts the spectator's gaze, itself a creation of the unnoticed camera, the camera which invokes the image of a perfect, natural world, a world with verisimilitude (1991, p. 115). In using these interpretive strategies, Trinh creates the space for the viewer (and listener) to critically appraise the politics of representation that structure the documentary text.

\section{Cultivating Reflexivity}

Learning from Trinh, I want to cultivate a method of patient listening, a reflexive method of looking, hearing and asking that is dialogical and respectful. This method will take account of my place as a co-constructor of meaning in this dialogic relationship. As an active listener (Bourdieu 1996), I will treat dialogue as a process of discovery. I will attempt to function as an empowering collaborator. I will use the reflexive interview as a tool of intervention (Burawoy 1998). I will use it as a method for uncovering structures of oppression in the life worlds of the persons I am interviewing. As a reflexive participant I will critically promote the agendas of radical democratic practice.

In so doing I hope to cultivate a method of hearing and writing that has some kinship with the kinds of issues Gloria Naylor discusses in the following passage:

"Someone who didn't know how to ask wouldn't know how to listen. And he coulda listened to them the way you been listening to us right now. Think about: ain't nobody really talking to you ... Really listen this time; the only voice is your own. But you done just heard the about the legend of Saphira Wade ... You done heard it in the way we know it, sitting on our porches and shelling June peas ... taking apart the engine of a car --you done heard it without a single living soul really saying a word" (Naylor 1998, p.1842).

But this is also a sociology, that understands, here at the end, that when we screen our dreams and our crises through the canvases and lenses that the cinematic and electronic society make available to us, we risk becoming storied versions of somebody's else's version of who we should be.

\section{Further Reading}

Altheide, D. 1995. An Ecology of Communication. New York: Aldine de Gruyter.

Altheide, D., \& Snow, A. R. 1991. Media Worlds in the Postjournalism Era. New York: Aldine de Gruyter.

Atkinson, P., \& Silverman, D. 1997. Kundera's Immortality: The Interview Society and the Invention of the Self. Qualitative Inquiry, 3, 304-325.

Bakhtin, M. M. 1986. Speech Genres and Other Late Essays. Austin: University of Texas Press.

Blumer, H. 1933. Movies and Conduct. New York: Macmillian.

Bourdieu, P. 1996. Understanding. Theory, Culture \& Society, 13, 17-37.

Brissett, D., \& Edgley, C. (Eds.). 1990. Life As Theater: A Dramaturgical Sourcebook (2nd ed.). New York: Aldine de Gruyter.

Burawoy, M. 1998. The Extended Case Method. Sociological Theory, $16,4-33$.

Butler, J. 1990. Gender Trouble. New York: Routledge.

Chow, R. 1995. Primitive Passions: Visuality, Sexuality, Ethnography and Contemporary Chinese Cinema. New York: Columbia University Press.

Denzin, N. K. 1991. Images of Postmodern Society: Social Theory and Contemporary Cinema. London: Sage.

Denzin, N. K. 1995a. The Cinematic Society. Thousand Oaks: Sage.

Denzin, N. K. 1995b. "Information Technologies, Communicative Acts, and the Audience: Couch's Legacy to Communication Research.”. Symbolic Interaction, 18, 247-268.

Denzin, N. K. 1997. Interpretive Ethnography. Thousand Oaks: Sage.

Denzin, N. K. 2000. "The Cinematic Society and the Reflexive Interview.". In J. F. Gubrium \& J. A. Holstein (Eds.), The Handbook of Interview Research (pp. 833-848). Newbury Park: Sage Publications.

Denzin, N. K. 2003. Performance Ethnography: Critical Pedagogy and the Politics of Culture. Thousand Oaks: Sage.

Denzin, N. K., \& Lincoln, Y. S. 2000. "Introduction: The Discipline and Practice of Qualitative Research.”. In N. K. Denzin \& Y. S. Lincoln (Eds.), Handbook of Qualitative Research (2nd ed.). Thousand Oaks: Sage.

Dillard, A. 1982. Living By Fiction. New York: Harper \& Row.

Eason, D. 1986. On Journalistic Authority: The Janet Cooke Scandal. Critical Studies in Mass Communication, 3, 429-47.

ESPN. 2000. "Sports Center: Sal Palitino Interview with Kurt Warner.". 31 January.

Fontana, A., \& Frey, J. H. 2000. The Interview: From Structured Questions to Negotiated Text. In N. K. Denzin \& Y. S. Lincoln (Eds.), Handbook of Qualitative Research (2nd ed.). Thousand Oaks: Sage.

Fontana, A., \& James, H. F. 1994. "The Interview: The Art of Science.". In N. K. Denzin \& Y. S. Lincoln (Eds.), Handbook of Qualitative Research (2nd ed., pp. 361-376). Thousand Oaks: Sage.

Goffman, E. 1959. The Presentation of Self in Everyday Life. New York: Doubleday.

Gottschalk, S. 2000. "Escape from Insanity: 'Mental Disorder' in the Postmodern Moment.”. In Dwight Fee (Ed.), Pathology and the Postmodern: Mental Illness as Discourse and Experience (pp. 18-48). Thousand Oaks: Sage.

Gubrium, J. F., \& Holstein, J. A. 1997. The New Language of Qualitative Method. Oxford: New York.

Gubrium, J. F., \& Holstein, J. A. 1998. Narrative Practice and the Coherence of Personal Stories. The Sociological Quarterly, 39, 163-187.

Guerrero, Ed. 1993. Framing Blackness: The African American Image in Film. Philadelphia: Temple University Press.

Heyl, B. S. 2000. "Ethnographic Interviewing.". In A. C. Sara Delamont \& Paul Atkinson (Eds.), Handbook of Ethnography. London: Sage Ltd. 
Holstein, J. A., \& Gubrium, J. F. 1995. The Active Interview. Thousand Oaks: Sage.

Holstein, J. A., \& Gubrium, J. F. 2000. The Self That We Live By: Narrative Identity in the Postmodern World. New York: Oxford University Press.

Jackson, M. 1998. Minimia Ethnographica. Chicago: University of Chicago Press.

Lopez, A. M. 1991. "Are All Latins from Manhattan? Hollywood, Ethnography, and Cultural Colonialism.”. In D. F. Lester (Ed.), Unspeakable Images: Ethnicity and the American Cinema (pp. 404-424). Urbana: University of Illinois Press.

Lyman, S. 1990. Civilization: Contents, Discontents, Malcontents and Other Essays in Social Theory. Fayetteville: University of Arkansas Press.

Mishler, E. G. 1986. Research Interviewing: Context and Narrative. Cambridge: Harvard University Press.

Naylor, Gloria. 1998. "Excerpt from Mamma Day." Pp. 1838-1842 in Patricia Liggins Hill (Ed.), Call \& Response: The Riverside Anthology of the African American Literary Tradition. Boston: Houghton Mifflin.

Oudes, B. 1989. From the President: President Nixon's Secret Files. New York: Harper \& Row.

Park, R. E. 1950. “An Autobiographical Note.”. In R. E. Park (Ed.), Race and Culture: Essays in the Sociology of Contemporary Man (pp. v-ix). New York: The Free Press.
Scheurich, J. J. 1995. A Postmodernist Critique of Research Interviewing. Qualitative Studies in Education, 8, 239-252.

Trinh, T. Minh.-ha. 1991. When the Moon Waxes Red: Representation, Gender and Cultural Politics. New York: Routledge.

Trinh, T. Minh.-ha. 1992. Framer Framed. New York: Routledge.

Trinh, T. Minh-ha. 1989. Surname Viet Given Name Nam.

Turner, V. 1986. An Anthropology of Performance. New York: Performing Arts Journal Publications.

Vecsey, George. 2000. "Kurt Warner Gives Hope to Others." New York Times, (Sports Tuesday):1 February: C29.

Vidich, A. J., \& Lyman, S. M. 1994. "Qualitative Methods: Their History in Sociology and Anthropology." In N. K. Denzin \& Y. S. Lincoln (Eds.), The Handbook of Qualitative Research (pp. 2359). Newbury Park: Sage.

Weiss, Philip. 1988. "Party Time in Atlanta." Columbia Journalism Review.

Norman K. Denzin iis Distinguished Professor of Communications, College of Communications Scholar, and Research Professor of Communications, Sociology and Humanities, at the University of Illinois, Urbana-Champaign. He is the author, editor, or co-editor of numerous books, including The Qualitative Manifesto, Qualitative Inquiry Under Fire, and Performance Ethnography: Critical Pedagogy and the Politics of Culture. 